\title{
Simultaneous-onset infectious spondylitis with vertebral fracture mimicking an acute osteoporotic vertebral fracture erroneously treated with balloon kyphoplasty: illustrative case
}

\author{
Noritaka Yonezawa, MD, ${ }^{1}$ Yuji Tokuumi, MD, ${ }^{2}$ Nobuhiko Komine, MD, ${ }^{2}$ Takaaki Uto, MD, ${ }^{3}$ Yasumitsu Toribatake, MD, ${ }^{4}$ \\ Hideki Murakami, MD, ${ }^{5}$ Satoru Demura, MD, ${ }^{6}$ and Hiroyuki Tsuchiya, $\mathrm{MD}^{6}$

\begin{abstract}
${ }^{1}$ Department of Orthopaedic Surgery, Saiseikai Kanazawa Hospital, Kanazawa, Japan; ${ }^{2}$ Department of Orthopaedic Surgery, Asanogawa General Hospital, Kanazawa, Japan; ${ }^{3}$ Department of Orthopaedic Surgery, Ishikawa Prefectural Central Hospital, Kanazawa, Japan; ${ }^{4}$ Department of Orthopaedic Surgery, Kouseiren Takaoka Hospital, Takaoka, Japan; ${ }^{5}$ Department of Orthopaedic Surgery, Nagoya City University Medical School, Nagoya, Japan; and ${ }^{6}$ Department of Orthopaedic Surgery, Graduate School of Medical Sciences, Kanazawa University, Kanazawa, Japan
\end{abstract}

BACKGROUND Early balloon kyphoplasty (BKP) intervention for acute osteoporotic vertebral fracture (OVF) has been reported to be more effective than the conservative treatment. However, complications of early BKP intervention are still unknown.

OBSERVATIONS A 71-year-old patient with OVF of L2 underwent BKP 2 weeks after symptom onset. Preoperative magnetic resonance imaging (MRI) and radiograph were compatible with new L2 OVF. Although computed tomography (CT) images revealed the atypical destruction of lower endplate of L2 as OVF, L2 BKP was planned. After BKP, his back pain improved dramatically. Two weeks after BKP, his lower back pain recurred. MRI and CT confirmed the diagnosis of infectious spondylitis with paravertebral abscess formation. With adequate antibiotic treatment and rehabilitation, he was symptom-free and completely ambulatory without signs of infection.

LESSONS Signal changes on the fractured vertebral bodies during initial MRI and fractured vertebral instability on radiograph can mislead the surgeon to interpret the infection as a benign compression fracture. If the patients exhibit unusual destruction of the endplate on CT imaging, "simultaneousonset" spondylitis with vertebral fracture should be included in the differential diagnosis. To determine the strategy for OVF, preoperative biopsy is recommended if simultaneous-onset spondylitis with vertebral fracture is suspected.

https://thejns.org/doi/abs/10.3171/CASE2135

KEYWORDS osteoporotic vertebral fracture; balloon kyphoplasty; spondylitis; osteoporosis

There are many reports on the clinical results of balloon kyphoplasty (BKP) for the treatment of osteoporotic vertebral fracture (OVF) ${ }^{1-7}$ BKP provides a more rapid relief of axial pain and improvement of function than the conservative treatment. Recently, Hoshino et al. reported that in patients with poor prognostic factors (high-intensity or diffuse low-intensity areas in fractured vertebrae on T2-weighted magnetic resonance imaging [MRI]), early BKP intervention within 2 months of symptom onset was more effective than the conservative treatment for improving the activities of daily living (ADLs) and quality of life and preventing vertebral body deformities at 6 months after injury. ${ }^{8}$ In the authors' report, applying BKP in patients with poor prognostic factors in the early stages may not only prevent disability and improve independence in elderly patients but may also reduce unnecessary hospitalization and medical costs. Recently, two additional studies have reported the outcomes of earlier BKP intervention for OVF patients within 4 weeks of symptom onset., 9

The early intervention of BKP for acute OVF is effective. However, complications and indications for early BKP intervention for acute OVF were unknown. Here, we present a case of pyogenic spondylodiscitis mimicking an acute osteoporotic vertebral fracture erroneously treated

ABBREVIATIONS ADLs = activities of daily living; BKP = balloon kyphoplasty; CRP = C-reactive protein; CT = computed tomography; MRI = magnetic resonance imaging; OVF = osteoporotic vertebral fracture; $\mathrm{WBC}=$ white blood cell.

INCLUDE WHEN CITING Published September 20, 2021; DOI: 10.3171/CASE2135.

SUBMITTED January 20, 2021. ACCEPTED July 27, 2021.

(C) 2021 The authors, CC BY-NC-ND 4.0 (http://creativecommons.org/licenses/by-nc-nd/4.0/). 

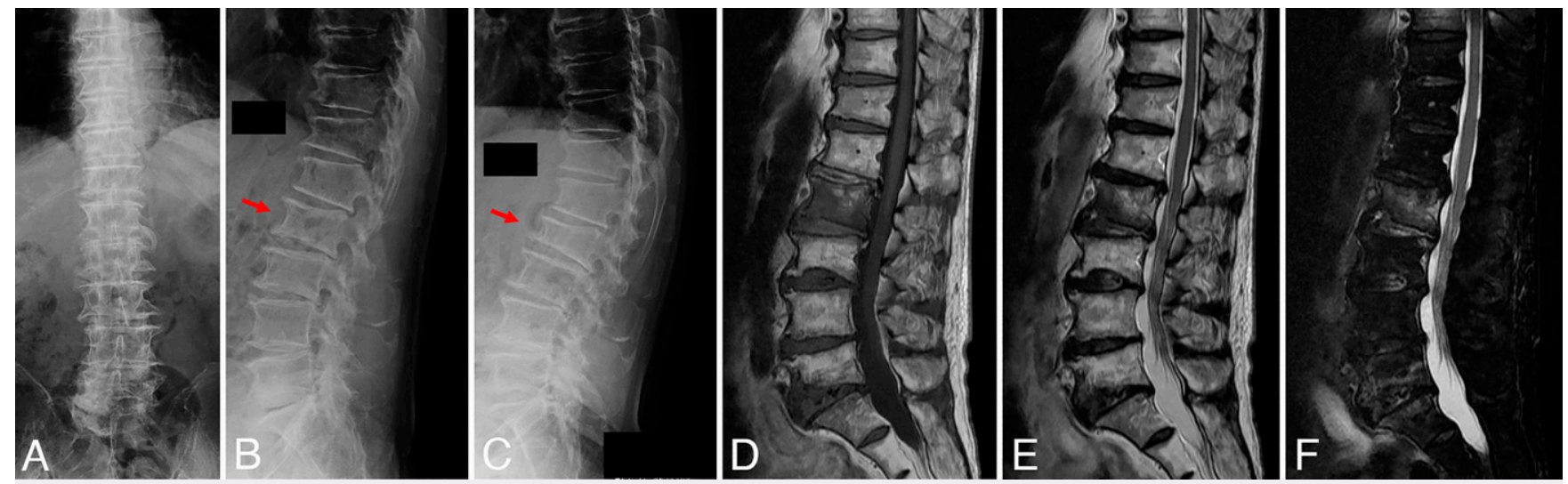

FIG. 1. A-C: Preoperative radiography and MRI of the lumbar spine in the supine position (A), lateral position (B), and sitting position (C). D-F: T1weighted MRI (D), T2-weighted MRI (E), and T2-weighted MRI (F) with fat suppression. The radiograph revealed fractured vertebral instability (red arrow). T1-weighted sagittal MRI revealed a low signal intensity lesion at L2, compatible with new L2 compression fracture.

with balloon kyphoplasty. This is the first case report regarding complications of early BKP intervention for acute OVF.

\section{Illustrative Cases}

A 71-year-old man was admitted to our hospital with progressive severe lower back pain for 2 weeks without a history of trauma. Plain radiographs revealed an unstable OVF in the L2 vertebra (Fig. 1). On admission, the patient was afebrile, his white blood cell (WBC) count was $7500 \mathrm{cells} / \mathrm{mm}^{3}$, and his C-reactive protein (CRP) concentration was $1.41 \mathrm{mg} / \mathrm{dL}$. The differential WBC count was $65.5 \%$ neutrophils, $2.1 \%$ eosinophils, $0.7 \%$ basophils, $19.0 \%$ lymphocytes, and $12.7 \%$ mononuclear cells. The erythrocyte sedimentation rate was not measured preoperatively. T1-weighted sagittal MRI revealed a low signal-intensity lesion at $\mathrm{L} 2$, which was compatible with new L2 OVF (Fig. 1). Although computed tomography (CT) revealed atypical destruction of lower endplate of L2 as OVF (Fig. 2) and relatively high bone mineral density (young adult mean, femur $91 \%$ ). Hence, L2 BKP was performed with $8 \mathrm{~mL}$ of cement (Fig. 3A and B). His back pain improved dramatically post-BKP.
Seventeen days post-BKP, however, he had a high fever $\left(38.5^{\circ} \mathrm{C}\right)$, and his WBC count was $8,100 / \mathrm{mm}^{3}$. His CRP concentration was 11.29 $\mathrm{mg} / \mathrm{dL}$. Urinary tract infection was suspected and oral administration of levofloxacin was initiated. Twenty days post-BKP, CRP concentration increased to $16.22 \mathrm{mg} / \mathrm{dL}$, and administration of ceftriaxone was initiated. Twenty-one days post-BKP, his lower back pain recurred. Twentysix days post-BKP, MRI revealed a bilateral epidural abscess at the treated L2 vertebral level (Fig. 3E). Forty-one days post-BKP, CT revealed destruction of the anterior wall and the upper endplate of the L2 vertebra (Fig. 3D). Administration of broad-spectrum antibacterial agents (meropenem and daptomycin) was initiated after the diagnosis of infectious spondylitis. Two months post-BKP, parkinsonism (rigidity, akinesia) developed, and administration of rotigotine was initiated after the diagnosis of Parkinson's disease. Three months post-BKP, the levels of inflammatory markers (sedimentation and CRP) became normal. Repeated MRI showed resolution of the abscess (Fig. 3F and G).

Six months postoperatively, the patient was discharged with symptomatic improvement. He was symptom-free and completely ambulatory without assistance. After 14 months, he had no complaints, neurological deficit, or signs of infection. Plain radiographs
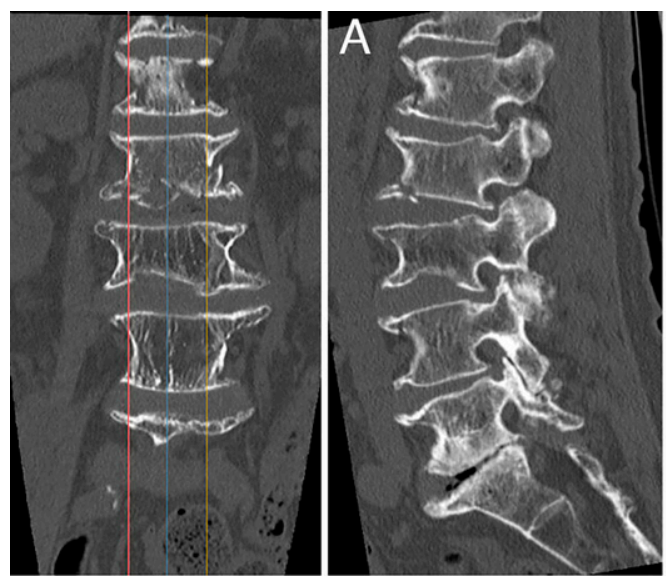

A B C
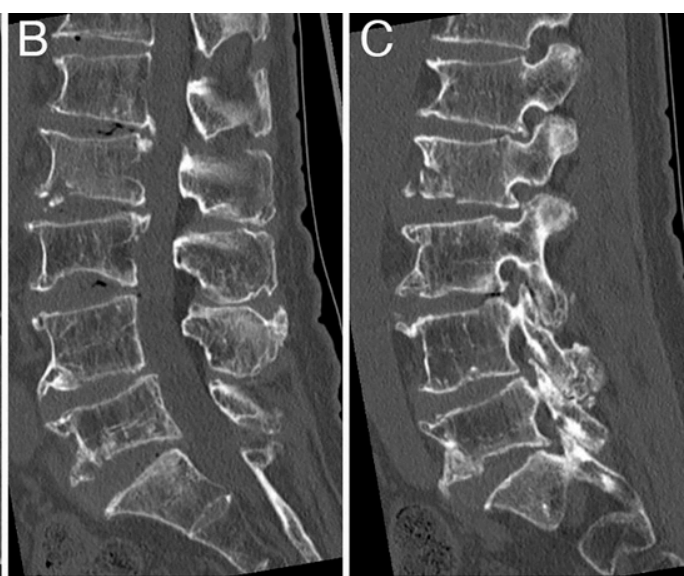

FIG. 2. Preoperative $C T$. CT revealed a recent fracture of the $L 2$ endplate. 

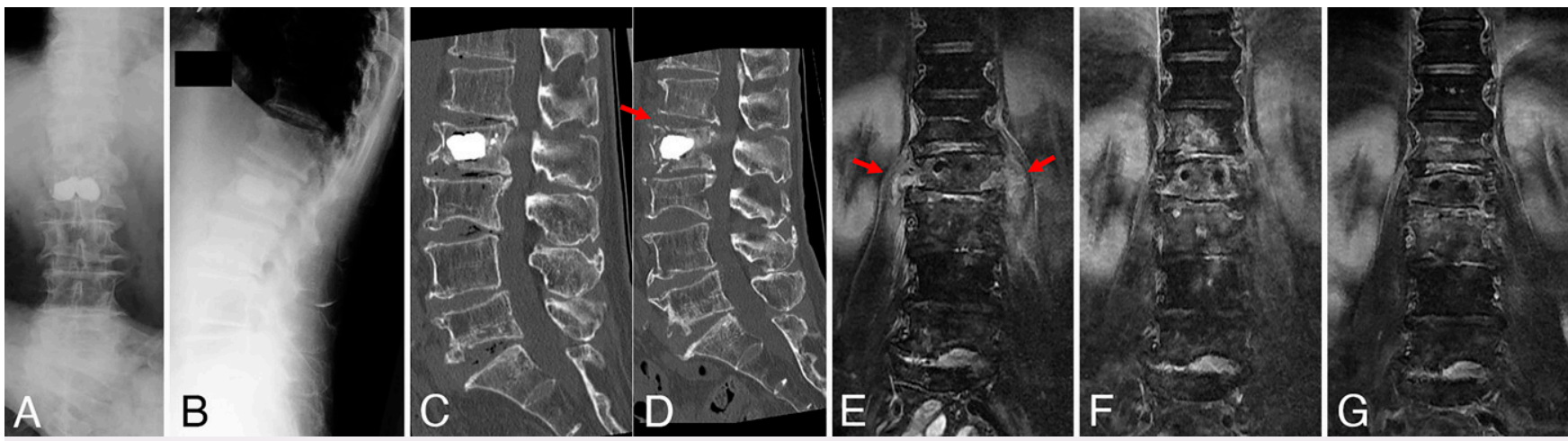

FIG. 3. A-D: Postoperative radiography and CT immediately after BKP (A and B), 5 days after BKP (C), and 41 days after BKP (D). E-G: Postoperative MRI 26 days after BKP $(\mathbf{E})$, MRI40 days after BKP $(\mathbf{F})$, and MRI 92 days after BKP $(\mathbf{G})$. Postoperative CT revealed the fracture of the upper endplate of the $\mathrm{L} 2$ vertebral body, which is compatible with spondylitis (red arrow). Postoperative MRI revealed a bilateral psoas abscess (red arrow). The psoas abscess reduced conservatively with antibacterial agents.

demonstrated massive bridging callus and well-stabilized affected vertebra with signs of radiographic bony union (Fig. 4).

\section{Discussion}

\section{Observations}

Spondylitis after cement augmentation is a life-threatening complication. In the last 2 decades, several cases of infectious spondylitis after vertebroplasty or kyphoplasty have been reported. ${ }^{11-32}$ However, the incidence of iatrogenic surgical infection after cement augmentation by vertebroplasty or kyphoplasty is still unknown. Table 1 shows the characteristics of infectious spondylitis cases (including our ase) following BKP or vertebroplasty, focusing on duration between symptom onset and surgery. Among them, 11 cases (73\%) underwent early cement augmentation within 1 month of OVF diagnosis. In some cases, vertebroplasty or kyphoplasty was performed for infectious spondylitis at the acute phase, misdiagnosed as acute OVF. Preoperative biopsy is widely used in kyphoplasty, and preoperative diagnosis, including biopsy, is considered essential for an accurate diagnosis. ${ }^{22}$
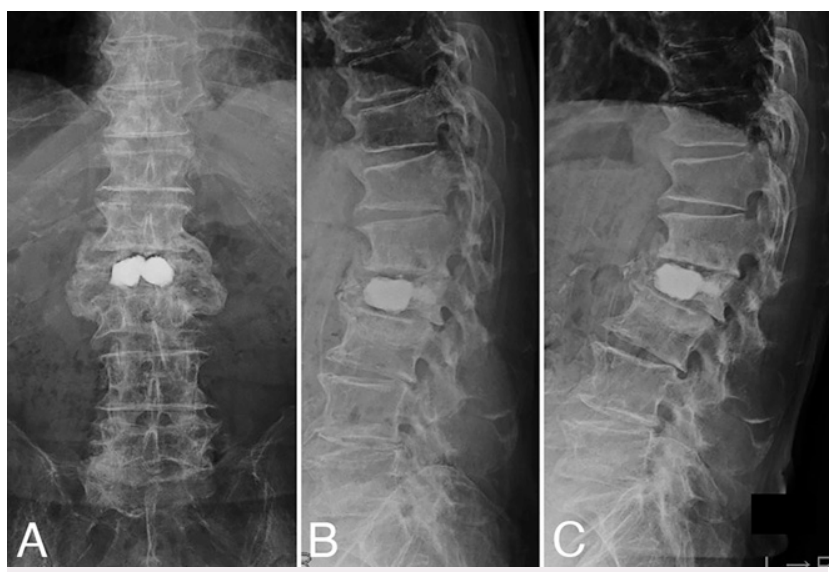

FIG. 4. Postoperative radiological findings 14 months after BKP in the supine position (A), lateral position (B), and sitting position (C). Postoperative radiography demonstrated a massive bridging callus and well-stabilized affected vertebra with signs of radiographic bony union.
In the current study, preoperative radiograph and MRI did not contradict imaging findings of acute OVF. However, preoperative CT revealed the complicated fracture of the lower endplate of the L2 vertebral body, which is atypical for acute OVF. In terms of relatively high bone density and no mechanism of injury, infectious spondylitis complicated with vertebral instability should be included as the differential diagnosis.

The main question that remained was whether our patient's vertebral fractures were the result of a preexisting unrecognized spondylitis or whether the spondylitis occurred after BKP. It is ultimately impossible to determine whether the patient had an infection preoperatively or whether it was a deep postoperative infection caused by the surgery. We consider that the patient may have had an infection preoperatively, and this may be supported by the following literature. In 2019, Fujiwara et al. retrospectively examined the MRI images of 168 osteoporotic vertebral fractures and reported the frequency and detailed location of the endplate injuries. ${ }^{33}$ They found that the vertebral endplates were injured in approximately $61 \%$ of the cases. It is noteworthy that the proportion of lower endplate injuries among all endplate injuries is very low (5\%). They also assessed the detailed location of the endplate injury (anterior, central, and posterior). Among all endplate injuries, the percentage of anterior injury of the inferior endplate, as in the present case, was $1.7 \%$, which is very rare. In 2020 , Uto et al. reported spontaneous vertebral body infection following OVF and demonstrated that the incidence rate of vertebral body infection among OVF patients was $0.7 \%$, and its occurrence led to serious events. ${ }^{34}$ In their report, the durations from OVF diagnosis to the diagnosis of vertebral body infection varied among the cases. Moreover, the CRP levels of some cases were normal during OVF diagnosis. The quick and slow manifestations of infection after the diagnosis of fracture were attributed to "simultaneous-onset" and "secondary" types of infection. ${ }^{34}$ In the simultaneous-onset type, the fractures occur almost simultaneously due to the initial infection, as shown in the present study. In the secondary type, OVF adversely affects ADLs and causes infection to pseudarthrosis of the vertebral body after bacillemia associated with pneumonia and urinary tract infection. ${ }^{34,35}$

Osteoporotic vertebral fractures with an unknown origin of injury are common in Japan, with a significantly aging population. In fact, it has been reported that the origin of injury is unknown in approximately 
TABLE 1. Characteristics of our case and reported cases of spondylitis following BKP or vertebroplasty

\begin{tabular}{|c|c|c|c|c|c|c|c|c|}
\hline $\begin{array}{c}\text { Authors \& } \\
\text { Year }\end{array}$ & $\begin{array}{l}\text { Age, } \\
\text { Sex }\end{array}$ & $\begin{array}{l}\text { Duration } \\
\text { (onset of } \\
\text { symptoms } \\
\text { after surgery) }\end{array}$ & $\begin{array}{l}\text { Type Of } \\
\text { Surgery }\end{array}$ & Level & $\begin{array}{l}\text { Duration } \\
\text { (surgery to } \\
\text { diagnose of } \\
\text { infection) }\end{array}$ & $\mathrm{PMH}$ & Organism & Outcomes \\
\hline Current study & $71, M$ & 23 days & $\mathrm{BKP}$ & L2 & 22 days & PD & Negative & $\begin{array}{l}\text { Normal } \\
\text { walking }\end{array}$ \\
\hline \multirow[t]{2}{*}{$\begin{array}{r}\text { Lai et al., } \\
2019^{12}\end{array}$} & $80, F$ & 7 days & VP & L1 & 4 months & $\begin{array}{l}\text { HT, CAD, peptic } \\
\text { ulcer }\end{array}$ & $\mathrm{Tb}$ & $\begin{array}{l}\text { Normal } \\
\text { walking }\end{array}$ \\
\hline & $90, F$ & 2 months & VP & T8-9 & 1 month & Gout & $\mathrm{Tb}$ & $\begin{array}{l}\text { On wheel } \\
\text { chair }\end{array}$ \\
\hline $\begin{array}{l}\text { Jia-Jia et al., } \\
2018^{13}\end{array}$ & $54, F$ & 20 days & Kyphoplasty & L3 & 7 months & $\begin{array}{c}\text { Obsolete } \\
\text { pulmonary } \mathrm{Tb}\end{array}$ & $\mathrm{Tb}$ & $\begin{array}{c}\text { No } \\
\text { neurological } \\
\text { deficit }\end{array}$ \\
\hline $\begin{array}{l}\text { Park et al., } \\
2018^{15}\end{array}$ & $71, \mathrm{~F}$ & 4 months & VP & L2 & 10 weeks & $\begin{array}{c}\mathrm{HT}, \mathrm{DM}, \\
\text { obesity, anemia }\end{array}$ & Parvimonas micra & $\begin{array}{l}\text { Normal } \\
\text { walking }\end{array}$ \\
\hline $\begin{array}{l}\text { Ge et al., } \\
2016^{17}\end{array}$ & $61, F$ & 7 days & Kyphoplasty & L1 & 2 years & DM & $\mathrm{Tb}$ & No sequelae \\
\hline $\begin{array}{l}\text { Zou et al., } \\
2015^{19}\end{array}$ & $68, F$ & $<1$ month & VP & L2 & 3 months & No history & $\mathrm{Tb}$ & $\begin{array}{l}\text { Normal } \\
\text { walking }\end{array}$ \\
\hline $\begin{array}{l}\text { Kang et al., } \\
2013^{22}\end{array}$ & $72, \mathrm{~F}$ & 2 weeks & VP & $\mathrm{T} 12$ & 4 weeks & $\begin{array}{l}\text { Pulmonary } \\
\text { tuberculosis }\end{array}$ & Tb (PCR-positive) & $\begin{array}{l}\text { Normal } \\
\text { walking }\end{array}$ \\
\hline $\begin{array}{l}\text { Schofer et al., } \\
2011^{23}\end{array}$ & $72, \mathrm{M}$ & 4 weeks & Kyphoplasty & L1 & 6 weeks & $\mathrm{PD}, \mathrm{HT}, \mathrm{CAD}$ & $\begin{array}{c}\text { group C hemolytic } \\
\text { Streptococcus }\end{array}$ & $\begin{array}{l}\text { Normal } \\
\text { walking }\end{array}$ \\
\hline $\begin{array}{l}\text { Ivo et al., } \\
2010^{25}\end{array}$ & $70, M$ & $>2$ months & Kyphoplasty & L1 & 2 weeks & $\begin{array}{c}\text { DM, COPD, } \\
\text { HC, TH, } \\
\text { oesophagitis }\end{array}$ & $\mathrm{Tb}$ & $\begin{array}{c}\text { Died from } \\
\text { multiple organ } \\
\text { failure }\end{array}$ \\
\hline $\begin{array}{l}\text { Olmos et al., } \\
2006^{29}\end{array}$ & $63, M$ & 3 months & VP & L3 & 10 days & No history & $\begin{array}{c}\text { S. marcescens, } S \text {. } \\
\text { maltophilia, } B . \\
\text { cepacia }\end{array}$ & Free of pain \\
\hline $\begin{array}{l}\text { Yu et al., } \\
2004^{31}\end{array}$ & $78, \mathrm{~F}$ & $>1$ week & VP & $\mathrm{T} 12$ & 1 month & NA & Negative & $\begin{array}{c}\text { Ambulate with } \\
\text { a walker }\end{array}$ \\
\hline $\begin{array}{l}\text { Walker et al., } \\
2004^{32}\end{array}$ & $64, F$ & $>3$ weeks & VP & $\mathrm{T} 11-12$ & 11 days & $\begin{array}{c}\text { DM, } \\
\text { osteoporosis, } \\
\text { RA }\end{array}$ & $\begin{array}{l}\text { Enterobacter } \\
\text { species }\end{array}$ & NA \\
\hline
\end{tabular}

B. cepacian = Burkholderia cepacia; $\mathrm{BKP}=$ balloon kyphoplasty; $\mathrm{CAD}=$ coronary artery disease; $\mathrm{COPD}=$ chronic obstructive pulmonary disease; $\mathrm{DM}=$ diabetes mellitus; $\mathrm{HC}=$ hypertensive cardiopathy; HT = hypertension; MRSE = methicillin-resistant Staphylococcus epidermidis; NA = not applicable; PCR polymerase chain reaction; PD = Parkinson's disease; $\mathrm{PMH}=$ past medical history; $\mathrm{RA}=$ rheumatoid arthritis; $\mathrm{Tb}=$ tuberculosis; $\mathrm{TH}=$ toxic hepatopathy; S. maltophilia $=$ Stenotrophomonas maltophilia; $S$. marcescens $=$ Serratia marcescens; VP $=$ vertebroplasty.

$43 \%$ of cases. $^{36}$ In this case, we considered that it was an osteoporotic vertebral fracture with an unknown mechanism of injury, but since the patient had a relatively high bone density, it was necessary to consider the possibility that a pathological fracture was associated with pyogenic spondylitis.

In the current study, both preoperative radiography and MRI indicated acute OVF. However, preoperative CT revealed the complicated fracture of the lower endplate of the L2 vertebral body, which is atypical for acute OVF. Infectious spondylitis complicated with vertebral instability should be included in the differential diagnosis. In this case, no preoperative or intraoperative biopsy was performed, and it is not clear whether the infection had already been established at the time of surgery. If a similar case is encountered, a biopsy procedure or follow-up of clinical symptoms and 
imaging studies should be performed. The patient should be carefully followed up for the appearance of infectious findings. If an infection is diagnosed, it should be treated as infectious spondylitis based on the causative bacteria.

\section{Lessons}

Signal changes on the fractured vertebral bodies during initial MRI and fractured vertebral instability on radiograph can mislead the surgeon to interpret the infection as a benign compression fracture. If the patients exhibit unusual destruction of the endplate on CT imaging, simultaneous-onset spondylitis with vertebral fracture should be included in the differential diagnosis. If simultaneousonset spondylitis with vertebral fracture is suspected, a preoperative biopsy or follow-up MRI should be performed to rule out infection.

\section{Acknowledgments}

We would like to thank Editage for English language editing

\section{References}

1. Garfin SR, Yuan HA, Reiley MA. New technologies in spine: kyphoplasty and vertebroplasty for the treatment of painful osteoporotic compression fractures. Spine (Phila Pa 1976).

2001;26(14):1511-1515.

2. Lieberman IH, Dudeney S, Reinhardt MK, Bell G. Initial outcome and efficacy of "kyphoplasty" in the treatment of painful osteoporotic vertebral compression fractures. Spine (Phila Pa 1976). 2001;26(14):1631-1638.

3. Belkoff SM, Mathis JM, Fenton DC, Scribner RM, Reiley ME, Talmadge K. An ex vivo biomechanical evaluation of an inflatable bone tamp used in the treatment of compression fracture. Spine (Phila Pa 1976). 2001;26(2):151-156.

4. Majd ME, Farley S, Holt RT. Preliminary outcomes and efficacy of the first 360 consecutive kyphoplasties for the treatment of painful osteoporotic vertebral compression fractures. Spine J. 2005;5(3):244-255.

5. Voggenreiter G. Balloon kyphoplasty is effective in deformity correction of osteoporotic vertebral compression fractures. Spine (Phila $\mathrm{Pa}$ 1976). 2005;30(24):2806-2812.

6. Garfin SR, Buckley RA, Ledlie J. Balloon kyphoplasty for symptomatic vertebral body compression fractures results in rapid, significant, and sustained improvements in back pain, function, and quality of life for elderly patients. Spine (Phila $P a$ 1976). 2006;31(19):2213-2220.

7. Wang $\mathrm{G}$, Yang $\mathrm{H}$, Chen K. Osteoporotic vertebral compression fractures with an intravertebral cleft treated by percutaneous balloon kyphoplasty. J Bone Joint Surg Br. 2010;92(11):1553-1557.

8. Hoshino M, Takahashi S, Yasuda H, et al. Balloon kyphoplasty versus conservative treatment for acute osteoporotic vertebral fractures with poor prognostic factors: propensity score matched analysis using data from two prospective multicenter studies. Spine (Phila Pa 1976). 2019;44(2):110-117.

9. Minamide A, Maeda T, Yamada $\mathrm{H}$, et al. Early versus delayed kyphoplasty for thoracolumbar osteoporotic vertebral fractures: The effect of timing on clinical and radiographic outcomes and subsequent compression fractures. Clin Neurol Neurosurg. 2018;173: $176-181$.

10. Zhou X, Meng X, Zhu H, Zhu Y, Yuan W. Early versus late percutaneous kyphoplasty for treating osteoporotic vertebral compression fracture: a retrospective study. Clin Neurol Neurosurg. 2019; 180(155):101-105.

11. Alpantaki K, Koutserimpas C, Kofteridis DP, Papastefanou S, Samonis G. Late-onset spondylodiscitis and psoas abscess, 5 years after percutaneous balloon kyphoplasty: a case report. Br J Neurosurg. 2019. DOI: 10.1080/02688697.2019.1672856.
12. Lai PJ, Liao JC, Chen LH, Lai PL. Tuberculous spondylitis after percutaneous vertebroplasty: a case series of 9 cases. Biomed J. 2019;42(4):285-292.

13. Jia-Jia S, Zhi-Yong S, Zhong-Lai Q, Hui-Lin Y, Xiao-Yu Z. Tuberculous spondylitis after vertebral augmentation: a case report with a literature review. J Int Med Res. 2018;46(2):916-924.

14. Liao JC, Lai PL, Chen LH, Niu CC. Surgical outcomes of infectious spondylitis after vertebroplasty, and comparisons between pyogenic and tuberculosis. BMC Infect Dis. 2018;18(1):555.

15. Park JW, Park SM, Lee HJ, Lee CK, Chang BS, Kim H. Infection following percutaneous vertebral augmentation with polymethylmethacrylate. Arch Osteoporos. 2018;13(1):47.

16. Youn MS, Shin JK, Goh TS, Lee JS. Minimally invasive percutaneous endoscopic treatment for acute pyogenic spondylodiscitis following vertebroplasty. Eur Spine J. 2018;27(Suppl 3):458-464.

17. Ge CY, He LM, Zheng YH, et al. Tuberculous spondylitis following kyphoplasty: a case report and review of the literature. Medicine (Baltimore). 2016;95(11):e2940.

18. Edidin AA, Ong KL, Lau E, Kurtz SM. Morbidity and mortality after vertebral fractures: comparison of vertebral augmentation and nonoperative management in the Medicare population. Spine (Phila Pa 1976). 2015;40(15):1228-1241.

19. Zou M-X, Wang X-B, Li J, Lv G-H, Deng Y-W. Spinal tuberculosis of the lumbar spine after percutaneous vertebral augmentation (vertebroplasty or kyphoplasty). Spine J. 2015;15(6):e1-e6.

20. Abdelrahman $H$, Siam AE, Shawky A, Ezzati A, Boehm H. Infection after vertebroplasty or kyphoplasty. A series of nine cases and review of literature. Spine J. 2013;13(12):1809-1817.

21. Lee JS, Choi SM, Kim KW. Triparesis caused by gas-containing extensive epidural abscess secondary to Aeromonas hydrophila infection of a thoracic vertebroplasty: a case report. Spine J. 2013;13(10):e9-e14.

22. Kang JH, Kim H-S, Kim SW. Tuberculous spondylitis after percutaneous vertebroplasty: misdiagnosis or complication? Korean $\mathrm{J}$ Spine. 2013;10(2):97-100.

23. Schofer MD, Lakemeier S, Peterlein CD, Heyse TJ, Quante M. Primary pyogenic spondylitis following kyphoplasty: a case report. J Med Case Reports. 2011;5(1):101.

24. Ha KY, Kim KW, Kim YH, Oh IS, Park SW. Revision surgery after vertebroplasty or kyphoplasty. Clin Orthop Surg. 2010;2(4): 203-208.

25. Ivo R, Sobottke R, Seifert H, Ortmann M, Eysel P. Tuberculous spondylitis and paravertebral abscess formation after kyphoplasty: a case report. Spine (Phila Pa 1976). 2010;35(12):E559-E563.

26. Lin WC, Lee CH, Chen SH, Lui CC. Unusual presentation of infected vertebroplasty with delayed cement dislodgment in an immunocompromised patient: case report and review of literature. Cardiovasc Intervent Radiol. 2008;31(suppl 2):S231-S235.

27. Lee CB, Kim HS, Kim YJ. Pyogenic spondylitis after vertebroplasty - a report of two cases. Asian Spine J. 2007;1(2):106-109.

28. Söyüncü Y, Özdemir H, Söyüncü S, Bigat Z, Gür S. Posterior spinal epidural abscess: an unusual complication of vertebroplasty. Joint Bone Spine. 2006;73(6):753-755.

29. Alfonso Olmos M, Silva González A, Duart Clemente J, Villas Tomé C. Infected vertebroplasty due to uncommon bacteria solved surgically: a rare and threatening life complication of a common procedure: report of a case and a review of the literature. Spine (Phila Pa 1976). 2006;31(20):E770-E773.

30. Schmid KE, Boszczyk BM, Bierschneider M, Zarfl A, Robert B, Jaksche $\mathrm{H}$. Spondylitis following vertebroplasty: a case report. Eur Spine J. 2005;14(9):895-899.

31. Yu SW, Chen WJ, Lin WC, Chen YJ, Tu YK. Serious pyogenic spondylitis following vertebroplasty-a case report. Spine (Phila $\mathrm{Pa}$ 1976). 2004;29(10):E209-E211. 
32. Walker DH, Mummaneni P, Rodts GE Jr. Infected vertebroplasty. Report of two cases and review of the literature. Neurosurg Focus. 2004;17(6):E6.

33. Fujiwara T, Akeda K, Yamada J, Kondo T, Sudo A. Endplate and intervertebral disc injuries in acute and single level osteoporotic vertebral fractures: is there any association with the process of bone healing? BMC Musculoskelet Disord. 2019;20(1):336.

34. Uto T, Tokuumi Y, Komine N, et al. Spontaneous incidence of vertebral body infection following osteoporotic vertebral fracture. Spine (Phila Pa 1976). 2020:45(12):E684-E687.

35. McHenry MC, Duchesneau PM, Keys TF, Rehm SJ, Boumphrey FR. Vertebral osteomyelitis presenting as spinal compression fracture. Six patients with underlying osteoporosis. Arch Intern Med. 1988;148(2):417-423.

36. Sakuma M, Endo N, Oinuma T, et al. Incidence of osteoporotic fractures in Sado, Japan in 2010. J Bone Miner Metab. 2014;32(2): 200-205.

\section{Disclosures}

The authors report no conflict of interest concerning the materials or methods used in this study or the findings specified in this paper.

\section{Author Contributions}

Conception and design: Yonezawa, Tokuumi, Murakami. Acquisition of data: Yonezawa, Tokuumi, Komine, Uto. Analysis and interpretation of data: Yonezawa. Drafting the article: Yonezawa. Critically revising the article: Komine. Reviewed submitted version of manuscript: Yonezawa, Tokuumi. Approved the final version of the manuscript on behalf of all authors: Yonezawa. Administrative/technical/material support: Toribatake. Study supervision: Murakami, Demura, Tsuchiya.

\section{Correspondence}

Noritaka Yonezawa: Saiseikai Kanazawa Hospital, Kanazawa, Japan. noritaka.yonezawa0105@gmail.com. 